\title{
My Daughter the Scientist? Mothers' Perceptions of the Shift in Their Daughter's Personal Science Identities
}

\author{
Donna Farland-Smith (Corresponding author) \\ Department of Teaching and Learning, The Ohio State University \\ 1680 University Drive, Mansfield, 44906 OH, USA \\ E-mail: farland-smith.1@osu.edu
}

Received: December 2, 2015 Accepted: December 24, 2015 Published: January 7, 2016

doi:10.5296/jei.v2i1.8670 URL: http://dx.doi.org/10.5296/jei.v2i1.8670

\begin{abstract}
This study reports on the perspective of mothers whose daughters underwent an extensive inquiry-focused interactive one-week science camp, which involved female middle school students and university scientists. This study focused on nine mother's perceptions of the impact the camp had on their daughter's science identities. Following the camp, parents were interviewed and reported that, among other things, their daughters had shifted to a much keener appreciation for science as a discipline, had a greater awareness of who scientists are, where their work, and what they do, as well as a broadened and more focused interest in science careers. Key to this paper is the profound ripple effect that these experiences with scientists had on the girls' science identities once returning to a school setting. Based on data collected, these experiences with scientists prompted students to participate more in school science and express more interest in science for as much as a year following the camp. The reflections shared by parents following their daughters' camp participation provide important insight for parents, teachers and informal educators in terms of how girls internalize these experiences in a way that effects their own perceptions of scientists and becomes incorporated into their individual science identities.
\end{abstract}

Keywords: Middle school, Girls, Science camp, Science identity

\section{Introduction}

How do girls internalize out-of-school science experiences? Do these experiences help shape and form girls' science identities? Can girls who are already interested in science become more interested? Previous studies have focused on parents' participation, parental engagement and parent involvement (Berger, 1995; Christenson \& Hurley, 1997; Hoover-Dempsey \& Sandler, 1995) and the relatedness of these parental actions to better 
outcomes in education. However, very few studies have examined parents' perceptions of their children as they engage in out-of-school science experiences. In this study, parental engagement is not an outcome or an expectation, but rather a lens through which to view middle school girls as they interact and construct their science identity in an out-of-school experience. It is already established that parents can support science learning by activities such as purchasing books for their children or taking them to science museums (Sun, Bradley, \& Akers, 2012). This study moves beyond the role of parental involvement and places parents as reporters. In this role, parents provide essential insight to gauge the changes witnessed in their daughters. In some cases, the parents do serve as an even more important part of the equation because they signed their daughters up for the camp before communicating with their daughters. In this way, the influence of parents is very complex, as parents often have a deliberate or unintentional role in providing opportunities for children that lead young girls away from or toward informal experiences in science.

\subsection{Literature Review}

The National Science Board publishes data on trends in science and technology in the United States. Despite accounting for half of the college-educated workforce, in 2010 women constituted $37 \%$ of employed individuals with a highest degree in a science and engineering (S\&E) field and 28\% of employed individuals in S\&E occupations (National Science Board, 2010). From 1993 to 2010, growth occurred in both the proportion of workers with a highest degree in a S\&E field who are women (increasing from 31\% to 37\%) and the proportion of women in S\&E occupations (increasing from 23\% to 28\%) (National Science Board, 2010). Women employed in S\&E occupations are concentrated in different occupational categories than are men, with relatively high proportions of women in the social sciences (58\%) and life sciences (48\%) and relatively low proportions in engineering (13\%) and computer and mathematical sciences (25\%) (National Science Board, 2010).

It also appears that as a country we are making progress in attracting girls to high-level science and math courses (National Center for Education Statistics, 2009). Girls have also made gains in terms of performance when compared with boys at middle and high school levels (National Center for Educational Statistics, 2010). Considering the historical gender gap in the educational attainment of women, the National Center for Statistics (2009) shared these promising results; however, the number of girls who are training to become scientists and engineers remains low (30\%), while the number of jobs requiring science and engineering is growing. This suggests the problem may be deeper than merely selecting science courses or performing as well as boys on standardized tests. It suggests that young girls have impressionable identities that are easily influenced, and may believe that in order for someone to pursue a career in science, they must identify with or possess stereotypical characteristics that are deemed culturally negative long before a career is formally considered.

While much is known about mentoring new teachers in science, the research concerning scientists mentoring individual students remains unexamined. A science camp was selected as the context for this study, as it had been established that this setting was successful in 
establishing a transformative experience for young female students, and broadening their perceptions about scientists (Farland-Smith, 2009). The data collected over the last four years appears to be enough to start guiding educators towards selecting, preparing, and maintaining successful interactions between middle-school girls and working scientists.

Unfortunately, at an early age many students form perceptions of scientists and science that are narrow, inappropriate, and inaccurate (Barman, 1997; Chambers, 1983; Finson, 2002; Fort \&Varney, 1989; Mead \& Metraux, 1957; Schibeci \& Sorenson, 1983). These inaccurate views of scientists are widely held by students from elementary through secondary school (Barman, 1996; Chambers, 1983). We have known for some time that girls between fifth and ninth grades limit their personal career choices in the areas of science and technology (Erb, 1981). This is because during this time of adolescence, girls are developing their identities and they either accept or reject certain notions of themselves because their identities are in continuous development and change as they reconsider and redevelop themselves (Giddens, 1991). It is commonly accepted that students categorize occupations based on gender, which affects the range of possible careers from which they choose (Gettys \& Cann, 1981). Several studies have found that students' subject interest is the key factor in educational choices, like selecting a career (Angell, Henriksen, \& Isnes, 2003; Lindahl, 2003). However, we also know that just because someone is interested in a subject this does not mean they will necessarily select that subject as a career; this is true especially for young women (Storen \& Arnesen, 2003). Central to understanding this problem, researchers have moved past focusing on interest and delved into the issue much deeper. They have found that in science education, girls, especially non-White girls, do not identify with science even if their achievement in science is high (Archer et al, 2013; D. Sadker, M. Sadker \& Zittleman, 2009). This highlights the importance of understanding the complexities and formation of girls' science identities. Due to the low number of female students interested in careers in science, it is clear that the need to attract females into science careers is critical.

One's science identity, as defined by Carlone (1994), includes demonstration of competent performance in relevant scientific practices with deep meaningful knowledge and understanding of science, as well as the recognition of oneself, along with the recognition by others, as a science person. The construction of this identity requires the participation of others as it is constructed socially within communities of practice (Tan \& Calabrese Barton, 2007). Lave and Wenger (1991) concur that students develop identities through engaging with the practices and tasks of the science class upon entering a community of practice such as the science classroom. Learning science in this community then becomes "a process of becoming to be, of forging identities in activity" (Lave \& Wenger, 1991, p.3). The community of practice is dependent on environmental factors inherent within that community as it is accepted that these identities are fluid and subject to change. According to Brickhouse and Potter (2001), having a science or technology-related identity does not mean that one will necessarily succeed in school if that science-related identity does not also reflect the values of the school-mediated engagement or if the students do not have access to the resources they need to do well in science. However, successful participation in school science, despite the lack of resources in a home environment, can be better facilitated when students have a 
science-related identity they can draw upon. If science identity is embedded within a particular context, such as a community of practice that includes one's attitudes, feelings, and intellect toward science, the term personal science identity is based on the introspective nature of an individual's science identity or the internal interactions within oneself, as defined by the Farland-Smith (2012). One's personal science identity is embedded within the science identity of his or her identities-in-practice. The identities-in-practice is the result of the external features one can see, such as classroom participation, etc. The personal science identity is deeper in magnitude, and is the sum of all experiences in science. It is important to discriminate between science identity and personal science identity, with the major difference between the two being internal reactions versus external actions. Identity construction is composed of science identity that is exhibited and revealed to others in a social setting. One's personal science identity may never be fully revealed to others because it houses all the experiences with science and scientists. The likes and dislikes, whether they have an opportunity to rise to the surface or not, are dependent upon the community of practice and opportunities, including a person's self-efficacy and comfort level with science. For example, a female may like something and not know why or what situation informed her choice.

All students engage in identity work while participating in science, whether purposefully or not (Tan et al, 2013). According to Tan et al. (2013), this identity work of young girls in science is grounded in both the positions individuals are assigned (or take on), as well as the tools, relationships, and practices available within the communities where they engage science. This is precisely the reason this researcher opted to explore the complex relationship between science identity and perception of scientists, as the girls were working directly (side-by-side) with scientists.

This study was designed for two specific purposes: 1) To gather perspectives from mothers about the impact of a summer camp on their daughters' science identities; 2) To explore the complex relationship between perceptions of scientists and identities-in-practice (science identities). Mothers are a valuable resource in reporting changes in their daughters' behavior, and would be most likely to discuss participation in camp and experiences with their daughters. This is why mothers were asked to participate in this research and provide comments following their daughter's attendance at the summer camp.

\subsection{Research Questions}

The overarching question for the study was perceived changes in girls' behavior by their mothers' following science camp attendance. Therefore, all nine parents were asked to discuss their daughter's behaviors in comparison to before and after the camp. They also discussed freely their reasons for seeking out the camp and signing up their daughters. The researcher then broke down the questions to four specific categories; 1) involvement/interest in school science; 2) verbalization of an interest in one or several science careers; 3) changes in interest level to participate in science-related events, or even informal science experiences; 4) noticeable differences in daughter's behavior. 


\section{Methods}

\subsection{Recruitment}

Girls were recruited for the camp by flyers in public, private, and home school settings for participation in the camp. In order to attend the Inspiring Young Female Scientists camp, students were required to present an application, which included a teacher's recommendation, along with a one-page paragraph about why they might want to attend. The application deadline was May 1 of the previous year and the principal investigator was responsible for evaluating applications and selecting candidates. All twenty-five applicants were invited to participate in the Inspiring Young Female Scientists program and received notification of acceptance on June 1. A nominal fee of $\$ 25$ was required for the girls to participate and scholarships were available if the parents provided documentation and demonstrated a need for one.

\subsection{Mothers}

All of the mothers who had middle school daughters who attended the Inspiring Young Female Scientists camp within the previous year were invited to participate in a face-to-face interview. The nine mothers who volunteered to participate in the study were married to the father of their daughters and ranged in age from 32-45 years. The signed a permission form for their involvement in the study and the researcher's ability to collect field notes on their daughter's participation. The camp took place at a mid-western university and all the girls and their parents who participated would be considered Caucasian and middle class. Each girl and her mother have been given a pseudo name for the purposes of this study. Of the nine mothers participating in the study, four home-schooled their daughters, while four sent their daughters to public school, and one sent their daughter to a private school. The grade ranges of the girls participating in the camp were grades 5-9. Six of the nine girls had participated in the camp for two summers. Five of the girls had both parents attend college and four had mothers only who had a college degree (with a range from a bachelors' degree to a doctoral degree).

It is important to disclose that the parents had some influence (possibly bias) in the girls attending the camp. For example, some parents verbalized that they found out about the camp and signed their daughter up first before telling their daughter about the camp. The parents were completely responsible for transportation so they had to 'buy into' the out-of-school experience. The best way to illustrate this point is to discuss the one girl who did not participate in the camp. Sarah was a freshman in a public high school. Her science teacher heard about the camp, signed her up, and paid the registration fees. The teacher then communicated with the mother how she thought Sarah would benefit from this experience and the mother promised to transport Sarah. Sarah never showed up to the camp. Based on this experience, it is safe to say that all parents of the girls attending camp "bought into science" to some degree. It is also a safe assumption to say that the girls "liked" science to some degree before attending the camp. 


\subsection{Parent Interviews}

Nine parents, who were all mothers agreed to participate from a group of twenty-five parents one year following their daughter's participation in camp. All nine agreed to participate in open-ended interviews. The mothers were asked four semi-structured questions about their daughter's camp experience and they were allowed to elaborate beyond each answer as much as they felt necessary. The four questions were: 1) Have your daughter's grades improved in science class?; 2) Has your daughter verbalized an interest in one or several science careers?; 3) Have you noticed a change in your daughter's interest level to participate in science-related events, or even informal science experiences (like science fairs and museum visits, etc)?; 4) As you reflect on your daughter's experience this summer, what was most valuable in your opinion? The parents' interviews were then triangulated with observation notes of each female participant at the camp and science journals.

\subsection{Science Camp as a Community of Practice}

At the science camp, middle school girls investigated real world problems in the areas of physical anthropology, chemistry, physics, geology, and biology. The girls spent each day with a different scientist investigating pertinent issues germane to that scientist's field of study. At the end of each day, each scientist discussed career opportunities in their particular field and the girls reflected in their journals about each day's experience. The girls were encouraged to design and complete a science investigation in one of the five areas: physical anthropology, biology, chemistry, physics, or geology and present at what was called the Science Exposition several weeks following the camp. Nine weeks after the camp, the middle school girls, along with their families and the five scientists, met for a Science Exposition Night in September at the university where the study took place. The evening was divided into two sections; the first half was spent listening to the girls self-reporting about perceptions of scientists and how their attitudes toward science changed during the camp experience. The second half of the evening was spent discussing the students' science investigation projects.

In addition to the researcher/camp director. The girls interacted with five scientists, two teachers, and two assistants who are former camp attendees and now in high school attended to assist with hands-on activities and serve as mentors to girls throughout the week. The teachers facilitated the activities and transitions between activities. The researcher took field notes and assisted with activities as needed. She also collected data and oversaw all aspects of the camp. The researcher was interested in the interactions between the girls and their mothers as evidence of the girls' personal science identity. Each morning for five consecutive days mothers dropped their daughters off at a summer-camp setting where the camp director/researcher and two teachers waited to greet them. Curious, excited, and eager, the students included creative young females who, after forming small groups, walked about a quarter-mile to a classroom. During the walk, the girls wanted to know what they were going to do that day. In short, they were excited to do science. Once to the classroom, the designated scientist of the day delivered an interactive experience for the girls. It should be noted here that these girls were not typical girls in a typical classroom setting. They were girls who liked science and thrived on challenges involving science or math. 
When the girls entered the classroom, they found their nametags placed on top of a composition notebook to be used as a science-camp journal. Each nametag was color-coded to organize the students into five groups. The camp director took care to ensure that students returning from previous years' camps were evenly spaced in groups. The arrangement of the tables allowed the girls to sit in pairs. Small buckets contained pencils, crayons, tapes, scissors, glue, and other miscellaneous supplies.

After the introductory activity for the day was completed, the scientists began their lesson. They interacted with the girls for about two and a half hours before an hour-long lunch break at noon. During lunch, the girls ate and played games outside when the weather was agreeable. The lunch break allowed the girls to get to know the scientist and one another and discuss their day so far.

After lunch, the girls continued to work with the scientist for another hour and a half. All of the afternoon activities were hands-on field or laboratory exercises. When the scientist was done for the day, the girls completed a wrap-up activity designed by the teachers, then wrote in their science journals. At the end of the day, the camp director escorted the girls back to the drop-off/pick-up location to meet their mothers.

\subsection{Nine Mother/Daughter Cases}

The following are the backgrounds of the nine mother/daughter parents' case studies.

\section{Case \#1: Beth \& Debra}

Beth is home-schooled by her mother, Debra and entering is seventh grade. She attended camp one summer. Both of the daughter's parents attended college. Before attending the camp she had no interest in science and was embarrassed if her mother, Debra told anyone she was going to science camp.

\section{Case \#2 Betty \& Jean}

Betty attends public school and is entering sixth grade. Her mother, Jean has a masters' degree in education and her father did not attend college. Betty attended the camp one summer. Jean approached the researcher to inform her about the dramatic changes she had witnessed in her daughter's behavior since attending the camp.

\section{Case \#3 Kim \& Lynn}

Kim is entering eighth grade and is home schooled. Both her parents hold degrees in science. Kim has attended the camp for two summers. Her mom is Lynn reports that her daughter Kim has always earned good grades in school. Both parents have degrees in science.

\section{Cases \#4 Sam \& Case \#5 Kelly and Sandra}

These two girls are sisters, both of whom are home schooled by their mother, Sandra. Case \#4 is Sam, who is entering sixth grade and Case \#5 is Kelly, who is entering eighth grade. Their mother and father both have bachelor's degrees. Both girls attended the camp for two summers at the time this study was conducted. 
Case \#6 Marie \& Tara

Marie attends a public school and is entering seventh grade. Her mother, Tara has a doctorate in mathematics education and her father did not attend college. Marie has attended the camp for two summers.

\section{Case \#7 Brenda \& \#8 Sally and Therese}

Similar to cases \#4 and \#5 both girls are sisters. Case \#7 is entering eighth grade and Case \#8 is entering sixth grade. They have attended the camp for two summers.

Case \#9 Rose \& Lynette

Lynette has one daughter, Rose, who is enrolled in a private school. Rose was identified early as gifted and Lynette remembered that Rose could already read before entering Kindergarten, but her parents chose to enroll her anyway in hopes of helping her socially. As a teenager, Rose still struggles socially while her academics excel. Like several other girls in the study, Rose received straight A's in school.

\section{Data Collection and Analysis}

Data obtained from the interviews with parents were transcribed verbatim and analyzed. The interviews were read and re-read several times throughout the transcription process. The parents' words, phrases, thoughts, feelings, and patterns were included in each transcript. Any words, thoughts, feelings or patterns that were common or repeated were highlighted and color-coded in a general category. Field notes were recorded during the week-long camp and the Science Exposition Night. The field observation notes were then read and re-read before being coded descriptively by the researcher as tentative trends emerged from the data. This was done to ensure reliable interpretation of the observations of the data and findings. The findings were then integrated with the theoretical constructs of the literature about girls' identities in practice. The following reports are parents' interviews of nine case studies.

\subsection{Journal Responses}

At the end of each day, the girls wrote answers to questions in their science journals. One question asked, "What did you like most about today?" On the last day of the week, students were asked to share what was their favorite day and why. All journals were collected after the science camp, copied, and returned to the girls.

\subsection{Field Notes}

In Analyzing Social Settings J. Lofland and L. Lofland (1995) describe several elements of social life appropriate to field research. The five elements selected for this study included; 1) Practices: recording notes of various kinds of behavior such as talking or reading books; 2) Encounters: recording notes of two or more people meeting or interacting; 3) Roles: the analysis of positions people occupy and the behavior associated with those positions: 4) Relationships: behavior appropriate to pairs or sets friends or sisters; 5) Groups: small groups such as friend cliques. Each researcher took notes as appropriate on these five elements. 


\subsection{Analysis}

In their journal responses, the researcher examined the girls' beliefs about science and scientists, as well as their beliefs about themselves as science people. Event-centered coding distinguished culture, climate, and context interactions. For example, when the girls talked with each other, the researcher recorded comments coded (CL) to indicate an example of climate next to their comments to each other. Emergent themes from this coding system were then established to highlight the personal and social interactions of the girls. The emerging themes will be discussed in detail in the results section. The researchers, to support or provide evidence for the research questions, then coded the entries.

\section{Findings}

Recall that this study was designed for two specific purposes: 1) To gather perspectives from mothers about the impact of a summer camp on their daughters' science identities; and 2) To explore the complexity of identities-in-practice (science identities) to include perceptions of scientists. The first purpose will now be discussed. The coding of the data elicited three major findings, which all participants discussed during the interviews with the mothers. These findings were also evident in the girls' observations during the camp, as well as in girls' self-expression and interactions during the Science Exposition Night. These major findings included improved interest, confidence, and self-efficacy in science. The positive experience and positive association with scientists directly affected the participants' science identity. As reported by the mothers, the girls' participation increased interest, self-efficacy, and improved confidence within each middle school girl. Table 1 will explain the overview of the findings in each of the three major themes of Interest, Confidence and Self-Efficacy. The end result was the feeling or verbalization of: (a) A belief that I, too, can be a scientist; (b) A broadened perception of scientists, specifically where they work, and what they do; (c) Positive experience and positive association with scientists; and (d) Frustration when subsequent classroom instruction was not relevant or hands-on. 
Table 1. Overview of themes emerging from the study

\begin{tabular}{|c|c|c|c|}
\hline & Interest & Confidence & Self-Efficacy in School Science \\
\hline $\begin{array}{l}\text { Common } \\
\text { Themes }\end{array}$ & $\begin{array}{l}\text { Broadened perception } \\
\text { of what scientists do, } \\
\text { where they work, and } \\
\text { their connection to the } \\
\text { world we live in }\end{array}$ & $\begin{array}{l}\text { Quality of daughter-scientist } \\
\text { relationships and the belief } \\
\text { that girls can be successful in } \\
\text { school science because of } \\
\text { these interactions }\end{array}$ & $\begin{array}{l}\text { Satisfaction with the experience } \\
\text { and the belief that she could be } \\
\text { successful in specific tasks } \\
\text { associated with school science }\end{array}$ \\
\hline $\begin{array}{l}\text { Mom's } \\
\text { Perspective }\end{array}$ & $\begin{array}{l}\text { All of a sudden my } \\
\text { daughter was seeing } \\
\text { connections in science } \\
\text { when they weren't } \\
\text { being made- it was } \\
\text { pretty strange. }\end{array}$ & $\begin{array}{l}\text { When my daughter wanted } \\
\text { to invite one of the scientists } \\
\text { over for dinner we \{husband } \\
\& \text { I\} knew something was } \\
\text { happening to her, I mean to } \\
\text { think of scientists as real } \\
\text { people you would invite over } \\
\text { for dinner? }\end{array}$ & $\begin{array}{l}\text { My daughter gets really frustrated } \\
\text { when she does not get a chance to } \\
\text { use the skills she has learned at } \\
\text { camp. She is so comfortable } \\
\text { doing science, she just starting } \\
\text { doing it at home and conducting } \\
\text { all different kinds of experiments } \\
\text { and talking about scientific } \\
\text { methods. }\end{array}$ \\
\hline $\begin{array}{l}\text { Quotes } \\
\text { from girls }\end{array}$ & $\begin{array}{l}\text { "I did not know THAT } \\
\text { was science" }\end{array}$ & $\begin{array}{l}\text { "I had never met a scientist } \\
\text { before coming here" }\end{array}$ & $\begin{array}{l}\text { On the college tours I have done I } \\
\text { have noticed fewer girls do } \\
\text { science than boys. I wonder why? } \\
\text { I think I can use this to my } \\
\text { advantage. I mean, some people } \\
\text { want to hire a woman. }\end{array}$ \\
\hline
\end{tabular}

One hundred percent of the mothers reported a transformation in their daughter as a result of the camp (regardless if it was a one or two year experience). The themes of this transformation will now be described in detail as 'a shift' from each girl focusing primarily on science as a necessary subject to viewing sciences as a worthwhile entity. Two cases were deliberately chosen to highlight each shift in an attempt to delve more deeply into girls' identity work.

\subsection{Shift in Interest}

Parents verbalized that science interest improved in all nine girls. The nine girls themselves also verbalized their increased science interest during the Science Exposition Night. Let us examine the case of Debra, one of the mothers in the study. Before attending the camp, her daughter, Beth, had no interest in science and was embarrassed if she told anyone she was going to science camp. Beth begged her mother not to tell others that her mother had signed her up for science camp. Debra could not understand her daughter's embarrassment, as she had signed up her other daughter (Beth's older sister) the previous year. Debra thought it was 
a good experience, so she signed up Beth. Her eldest child, Lucy, was already interested in pursuing a science career, and the camp helped her to focus on which career she wanted. Debra reported that Beth cried as she dressed for the first day of camp. During the interview, Debra asked the researcher if she could recall that her daughter was late on the first day. The reason she was late, she reported, was because Beth was crying in the parking lot and pleading with Debra not to leave her there. Debra said it took nearly forty-five minutes to convince Beth to try the camp for the first day. Debra remembered being surprised when she picked up Beth from camp that first day as Beth told story after story of her adventures with enthusiasm. Beth was now looking forward to participating in the crime scene on "Chemistry Day". Debra described her daughter's shift in interest as immediate. Each morning for the remainder of the week Beth dressed with anticipation of the day. Each afternoon she was filled with stories of how she enjoyed the day's activities. The only tears Debra reported seeing after the first morning were on the last afternoon; by the end of the week, Beth cried because she had to leave camp (D. Metzger, personal communication, September 21, 2009).

Her mother, who is her primary teacher, reported that she felt this out-of-school science experience was very beneficial for her daughter's identities-in-practice for the shift in interest her daughter experienced. She attributed this benefit to what she described as the unique environment which supported girls in science and encouraged them to participate in science thinking. Debra reported that her daughter now is more open about the possibility of science as a career. While Debra believes Beth will ultimately not select a science career because her daughter (at the time of this interview) was still talking about a career in accounting, Beth has verbalized an interest in forensics and physics. Her mother, Debra, is pleased that Beth is no longer turned off by science because she believes her daughter is very math minded. The mother attributes this transformation, which she described as "opening her daughter's mind to a bigger world", to the week-long summer camp experience (D. Metzger, personal communication, September 21, 2009).

Since the camp, her daughter expressed interest in attending an earth science class at a local private school. Debra signed her up and was happy to report that at the time of this interview Beth was receiving A's in the course. Prior to this out-of-school science experience, Beth had always been taught at home. Her daughter never expressed an interest to learn about science formally from another teacher and for this reason and the reasons state above, Debra now describes her daughter to be much more interested and much more positive about science than before the camp. Debra reports her daughter would often roll her eyes at science-related field trips and activities, but appears now to be much more interested and inquisitive about science in general (D. Metzger, personal communication, September 21, 2009).

Several other parents were quick to mention how much their daughters enjoyed meeting other girls who like science and who now are not embarrassed about liking it. They, too described the shift from embarrassment to interest. The social interactions with other girls who liked science helped dismantle some stereotypes about science - in particular, that science can be cool and it is not only limited to geeks!

Betty is another home-schooling mom who witnessed changes in her daughter, Jean during 
and following the camp experience. Betty's observations and interactions with her daughter led her to approach the researcher to inform her about the dramatic transformation she witnessed in her daughter's behavior since attending the camp. Betty described Jeane as a "good student" before the camp, a student who was always diligent about her work, but proceeded through science as work not passion. Betty shared several stories with the researcher when interviewed, but spent the most time discussing an afternoon that her daughter insisted she stop the car to get a close-up view of a rare tree species. Jean was screaming at the top of her lungs, "please, please stop the car". When they got out of the vehicle and approached the tree, her daughter talked about the tree in a lovingly appreciating way, which was out of character for the girl. This is when her Betty first noticed the difference in Jean and her seriousness about science following the camp. Betty also reported that Jean frequently said during the week, "Well, I didn't know that was science" (B. Johnson, personal communication, September 9, 2009).

Betty clearly discussed the shift she felt the camp had on her daughter's school science experience. Following the science camp experience, her daughter was much more conscientious about her science work and put a great deal of time into science projects; this was a shift in her daughter's previous behavior. Betty described two (projects) her daughter was assigned since the camp, a portfolio of the rock cycle and a timeline of Marie Curie, both of which she spent extensive hours on. Before the camp, she would have hurried through with no interest in the topics. After the camp, she took her time with science homework, so much so that Betty described that her daughter spent the greatest portion of her homework time on science, often extending her efforts beyond the assignment. After Betty discussed the shift in terms of time on task, she provided her daughter's report cards which displayed an academic improvement in terms of the letter grade in science when compared to the previous year. Betty described her daughter as someone who strives for A's now. The shift in science as academics has also appeared to change her daughter's thoughts about wanting to be a teacher or author. Since camp, she has expressed a serious interest in environmental engineering, a career not previously mentioned before the out of school experience (B. Johnson, personal communication, September 9, 2009).

Recall that Betty had previously contacted the researcher about her daughter's new behaviors, which Betty felt contributed to a new interest in science following the camp. Betty was also struck by an incident where her daughter came home with a flyer from a local science center and demanded her mother sign her up right away. This struck Betty as odd because her daughter had never done anything like this before and considering the event on the flyer was not a field trip during the school day, but instead an invitation to attend a Saturday for girls in science programs, it was even more peculiar to Betty. She came home and simply said, 'Mom, I have to go.' Betty registered her with some hesitation, telling herself she was not going to be mad if she drove one hour to the science museum and her daughter refused to go in. Betty expected her to back-out of attending, based on prior behavior. Several times before her daughter had refused to go into extra-curricular events after signing up. However, she went on her own, without any prompting from Betty, and to her surprise, enjoyed the day (B. Johnson, personal communication, September 9, 2009). 
During the interview process, parents praised the summer camp design and the literal side-by-side experience for enabling their daughters to have a first-hand experience with scientists. Most parents reported that as a result of those side-by-side experiences, their daughters are now more interested than ever before about the idea of careers in science.

\subsection{Shift in Confidence}

"I can't do science", "Science is too hard" and "I am not smart enough" are common misconceptions that turn away young girls from an interest in science. However, interviews with parents about their daughters' experiences at the camp mentioned in this paper indicated that students quickly overcame any such misconceptions. Moreover, girls became more confident in themselves as young scientists and were confident and comfortable when interacting with scientists in the camp.

Tara, a mom of one young girl, felt that the interactions with scientists were the most valuable experience for her daughter out of every other experience she had had up to that point in her life. Tara does not recall any other place her daughter would have this opportunity. Her daughter came home talking about Dr. Joe and Dr. Dawn. It was obvious the girls felt personally connected to the scientists and it affected Tara's daughter's ability to see herself as a scientist. Tara thanked the researcher for this experience in the interview because now her daughter sees science careers (in general) as attainable, and she reported that her daughter identifies with scientists, something never previously observed. Before the camp, her daughter was not even thinking about a career in science, but now that's all she thinks about (T. Bucci, personal communication, August 9, 2009).

Tara went on to express her gratitude for her daughter's (Marie) participation because this was an experience that was completely unique. When the researcher asked her to explain what she meant, Tara said this was not an experience she could "buy" for her daughter. It was just that, an experience that Tara believed at the time of the interview had a profound effect on her daughter. Tara giggled as she recalled her daughter wanting to invite one of the scientists she met at the camp over to her house for dinner. Since the experience, her daughter has also mentioned several times, 'I could study dolphins like Dr. Dawn studies primates, right? She asks this in a way seeming to search for her mother's approval in this career choice. Tara also recalled that her daughter's shift in confidence transitioned over to her daughter's participation in the science fair at her school. Tara believes that the experience she gained in scientific methods provided her daughter with confidence to participate in the science fair. Because the camp was the only place she received this information about various scientific methods, Tara was certain the camp was the reason for this shift. Tara went on to discuss her motivations for signing her daughter up at science camp. She admitted she did not really want or expect her daughter to become a scientist, but one of the most rewarding things about participating in the camp was that her daughter left thinking she 'could' be a scientist. Tara believes that defining moment, her daughter coming away with the perception that she CAN be a scientist if she chooses, remains invaluable. Confidence and the belief that I, too, could be a scientist were seen immediately following the camp experience ( $\mathrm{T}$. Bucci, personal communication, August 9, 2009). 
Lynn has homeschooled her daughter, Kim, since she was school-age. Kim has always earned good grades. However, since camp Lynn has noticed that Kim demonstrates more confidence in the sciences. When asked to describe what she means, Lynn explained that Kim often says, 'Oh yeah, this is like what we did at science camp.' However, what was even more interesting as Lynn talked about her daughters' experience was Lynn's observation that it [the camp] has also sparked her 'sense of wonder'. She was very excited to learn there are other people in the world who get excited about science. This shift in confidence can be described as moving from novice to expert. Lynn explained that both she and her husband are scientists so it was very natural for Kim to be a scientist (L. Sgambellone, personal communication, August 13, 2009).

However, what was surprising to Lynn was that after the camp experience, Kim's behavior changed in an interesting way. When pressed further, she proclaimed all of the sudden, "On her own, she tracked and recorded toads in our yard ... (and) created an elaborate display to record this data." This was unusual because before she would have asked us for help. Lynn fully attributed this to the camp experience, saying that it simply gave her more confidence, like for instance in displaying her data. Before camp she would have said, I have to get this right. After camp, she felt more confident to display what she observed and realized as long as she could support what her data said would in fact be right. Lynn also explained, she used to be interested in one or two topics, but now she sees the connections between the sciences. She used her hand-held microscope from the camp to answer the question: What is growing on top of the poinsettia at Christmas? The answer was mold. As her mom and home-school instructor, Lynn was happy to see her interact with other girls who were excited about science. She reported, "I think that helped her confidence overall" (L. Sgambellone, personal communication, August 9, 2009).

\subsection{Shift in Self-Efficacy}

In science, those who have a strong belief that they can succeed in science tasks and activities will be more likely to select such tasks, work hard to complete them, and persevere in the face of difficulty. Therefore, while it is important for girls to "like" science and be interested in it, they benefit most from self-efficacy, or the belief in their ability to succeed in science tasks, courses, and activities if they are to remain in the field of study. Bandura (1994) defines self-efficacy as "people's beliefs about their capabilities to produce designated levels of performance that exercise influence over events that affect their lives" (p.71). Self-efficacy is best described in future behavior (Woolfolk, 2003). Self-concept is developed as a result of internal and external interactions using other people or other aspects of the self as frames of reference (Woolfolk, 2003). Self-efficacy focuses on one's ability to successfully accomplish a particular task with no need for comparisons. Also, self-efficacy is context specific, meaning it varies depending on the subject or task. Self-efficacy is concerned with judgments of personal competence; self-esteem is concerned with judgments of self-worth. The following two cases were selected because they were both mothers of very academically successful girls, who might be misinterpreted by some as having high self-efficacy before the camp. One might look at these girls and question how their self-efficacy could improve or shift. This is precisely why the researcher linked the last theme of frustration with 
self-efficacy. Frustration occurred when classroom instruction they received following the camp was not relevant or interactive. Parents were quick to observe that their daughters expected science in the classroom to be as exciting as that which was provided at summer camp. Not surprisingly, in recent years many have insisted that science needs to be taught in a more exciting, challenging, and realistic fashion if students' interests are to be piqued. This is especially important in teaching young students whose perceptions of scientists are only just forming.

Sandra has two very engaged, highly successful girls in middle school. Both girls, Sam and Kelly, are friendly, down to earth, and easy to talk to. Sandra's first response to the interview was, "I am not sure how I can help you- I mean the girls grades did not improve as a result of being at camp. They both received straight A's before and after the camp. My oldest daughter, Sam wants to be a marine biologist. My youngest daughter Kelly does not know yet." Upon further questioning, Sandra revealed that Kelly does not like her teacher this year; however, she is still doing well. Sandra thought it was unusual that her daughter Kelly keeps talking about the science camp nearly one year after the experience. Kelly has brought up science camp often and wonders why the science classroom can't be more like camp (C. Adler, personal communication, September 10, 2009).

Sandra reported that the first summer her daughters attended science camp, they went to math camp. Sandra explained further, "They had attended science camp first, so they were extremely disappointed with math camp." "In fact," Sandra said, "They never want to go back to math camp again, but they were adamant that I sign them up for science camp and make our summer plans around the science camp." Sandra went on to explain, "These girls have a lot of choices about what activities to participate in; however, they look forward to it (science camp)." Sandra's youngest daughter, Kelly even went so far as to make sure her aunt (who is habitually late) would not be late in dropping her off to science camp one morning because she didn't want to miss anything and be behind for the day's activities. "As parents, this is not an experience we have to talk them into doing... I think this experience has shifted their frustration point with math and science (making it lower), because they believe in what they are doing, know they are capable, and want to be challenged to find answers" Sandra said (C. Adler, personal communication, September 10, 2009).

After the camp experience, Rose, completely changed her career trajectory. Previous to attending camp, Rose always wanted to be a dancer or an actor and after her camp experience she wanted to be a chemist or a marine biologist. Lynette is not certain when this change in career happened, and possibly thought it might be caused by maturation versus the camp experience (H. Henderson, personal communication, September 15, 2009).

Lynette felt like the camp was most helpful to Rose as she met others girls who liked science. Lynette did not really expect the camp to help her academically, since she was so advanced, but she was pleasantly surprised when Rose had the comfort level to apply for other camps and eventually go away overnight. Lynette felt like this positive association with the first camp she attended helped her opt for future camps. Lynette also described what she called "confidence." Lynette described Rose, as "comfortable in her own skin now and learned how 
to talk to others in an academically challenged setting" (H. Henderson, personal communication, September 15, 2009). Her daughter, who had never been in a setting that was quite like this before, "where it was cool to know a lot." Lynette exclaimed, "This helped her shift from the odd girl and be comfortable in her own skin; she is no more odd girl out." She went on to express her gratitude, "Rose now believes she can be successful in science and is no longer afraid to express this socially. For that reason, the camp experience was priceless for us as a family.” (H. Henderson, personal communication, September 15, 2009).

\section{Discussion}

The primary aim of this study was to gather perspectives from mothers about the impact of a summer camp on their daughters' science identities. This is the first investigation to suggest that parents' observations and interactions with their daughters play an important role in issues of personal science identity. The researcher also sought to explore the complexity of identities-in-practice (science identities) to include perceptions of scientists. The results indicate that girls involved in the camp (who came liking science) were able to improve their interest, confidence, and self-efficacy. Often times, we focus on getting students (especially girls) to "like" science, and do not explore how to increase interest, confidence, or self-efficacy.

Of the three findings, let us first discuss interest. One might think it's difficult to get someone who begins as interested to move to a deeper level of interest. Let's explore how the parents in this situation described this phenomenon. Summer camps that include a partnership between a university campus and public schools enable children to experience the excitement of doing science, which enormously impacts children's learning and interest in science (Rodriguez, 1998). These summer experiences also tend to carry over into children's classroom experiences. For example, teachers report that many of their students who attended a summer camp become leaders in the classroom in areas of science and problem solving. How girls craft an interest in science through participation in their out-of-school experiences can impact when and how girls seek to pursue participation in their science classrooms (Tan et al, 2013). In this study, parents reported that the shift in interest experienced by camp participants was not limited to academics, but to experiments the girls conducted themselves, as well as a narrowing of specific career choices.

A second theme was a shift in confidence. The increased confidence gained from the girls' experience with scientists seemed like a natural transition to increased academic confidence. Girls have few positive role models to encourage them to overcome their self-doubt. Where these role models are available, the evidence is that girls do well (Siraj-Blatchford \& Mayo, 2012). A connection appears between the girls working side-by-side with the scientists and the parents' perceived increase in the girls' confidence. These informal learning activities, defined as educational and occurring in a setting other than a traditional school (for example, a trip to a museum or zoo, or summer camp experience) can positively impact attitudes and achievement in science (Dori \& Revital, 2000). Bandura's (1986) Social Learning Theory proposed that people tend to avoid tasks in which they lack confidence (Kaya \& Lundeen, 2010). Therefore, to encourage girls who already like science it is essential to improve their 
confidence in their ability to be successful in science.

A third theme was a shift in self-efficacy. The third theme is important because it is connected to future behavior of the girls and not just limited to the classroom setting. As we have previously mentioned it is important for girls to "like" science and be interested in it, they benefit most from self-efficacy, or the belief in their ability to succeed in science tasks, courses, and activities if they are to remain in the field of study. Self-efficacy relates to the girls' personal science identity because it is a construct of a specific task, like school science instruction. In this way, this one experience of participating in the science camp actually resides within each girl and has the potential to impact the participants for years beyond.

Last, the researcher also sought to explore the complexity of identities-in-practice (science identities) to include perceptions of scientists. Identity construction and interests are two important factors influencing girls' educational choices. Their education and future job have to be interesting and meaningful in order to harmonize with their identity and to open up opportunities for self-actualization and self-development (Schreiner \& Sjoberg, 2007). An educational choice is an identity choice (Schreiner \& Sjoberg, 2007). A summer science camp experience, like the one described in this paper, can be invaluable in fostering future career choices in science, mathematics, technology and engineering. Such experiences can greatly reinforce a child's educational experience. This helps to explain why many parents strive to find experiences outside of school for their children in hopes of reinforcing academics and broadening student perspectives. Research suggests that greater parent involvement in their children's science learning, directly or indirectly, can lead to better achievement in science (Ho, 2010; Szechter \& Carey, 2009; Tare et al., 2011). These types of experiences also are beneficial in prompting students to socialize outside their normal and comfortable circle of friends. These are just some of the reasons why informal science experiences, are beneficial.

Calabrese Barton (1998) suggests pedagogy in the science classrooms should include the awareness that students are struggling for identity and representations. Based on this, scientific literacy should include some introspection as to how girls see themselves within and outside the world of science. In this setting, parents provided a valuable opportunity to capture shifts or changes in behavior in girls' personal science identities. All of the mother's reported the girls had an increase in their ability to complete science tasks once returning to each of their "traditional" science classrooms.

\section{Conclusions}

The shift in a daughter's self-confidence, interest, and self-efficacy then caused a shift in their mother's idea that their daughter could be a scientist. All of the mothers made reference to their ideas changing about their daughter's careers during the post camp experience. Helen remarked, "I just sent my daughter to camp because I thought it was a good thing. I never expected her to walk away wanting to actually be a scientist." Tara reported being more open to her daughter's career choice following the camp. Her particular interview was very insightful because she verbalized that she did not care if her daughter actually become a scientist or not, but she cared that her daughter now thought she COULD become one, and it was this shift that was most important to Tara. Despite the different school environments and 
educational backgrounds of the nine mothers discussed in this study, each of them verbalized that their daughters had more positive interest and heightened awareness of scientists and science following this summer camp and side-by-side experience with scientists. The reflections shared by parents following their daughters' experiences provides important insight for science educators, in terms of communicating the role of scientists to girls. This research demonstrates that perceptions about science and scientists can be changed both by participants and their mothers. Many of the mothers seemed amused when they remarked, "My daughter, the scientist?, hadn't quite thought of her that way, but it works now." Lynette's daughter is currently looking at colleges to enroll in a chemical engineering program. We won't know until several more years which girls from this experience actually selected science as a career, but for now the mothers who enrolled their daughter in this community of practice are getting used to the idea of calling their daughter a scientist.

\section{Limitations}

The size of this study is certainly a limitation with a sample of nine girls and their mothers. As mentioned previously, it is possible that this sample was bias because the parents had some influence as to whether or not the girls attended the camp and therefore, it is likely that the parents would most likely be pleased if it had a positive, noticeable impact of their daughters. It is important to mention that the parent perspective offers a view few researchers have examined and for that reason this study is important.

\section{References}

Angell, C., Henriksen, E., \& Isnes, A. (2003). Why learn physics? Others can take care of that! Physics in Norwegian Education: Content-perceptions-choices. In D. Jorde \& B. Bungum (Eds.), Science Education Perspectives, Research \& Development Oslo: Akademisk (pp. 165-198).

Archer, L., Dewitt, J., Osborne, J., Dillion, J., Willis, B., \& Wong, B. (2013). “Doing” science versus "Being" a scientist: Examining 10/11-year-old schoolchildren's constructions of science through the lens of identity. Science Education, 94(4), 617-639. http://dx.doi.org/10.1002/sce.20399

Bandura, A. (1986). Social foundations of thought and action: A social cognitive theory. Englewood Cliffs, NJ: Prentice-Hall.

Barman, C. (1997). Students' views of scientists and science: Results from a national study. Science and Children, 35(1), 18-23.

Berger, E. H. (1995). Parents as partners in education: Families and schools working together. Englewood Cliffs, NJ: Prentice Hall.

Brickhouse, N. W., \& Potter, J. T. (2001). Young women's science identity formation in an urban context. Journal of Research in Science Teaching, 38(8), 965-980. http://dx.doi.org/10.1002/tea.1041

Calabrese Barton, A. (1998). Teaching Science with homeless children: Pedagogy, 
representation, and identity. Journal of Research in Science Teaching, 35(4), 379-394. http://dx.doi.org/10.1002/(SICI)1098-2736(199804)35:4<379::AID-TEA8>3.0.CO;2-N

Carlone, H. B. (1994). The cultural production of science in reform-based physics: Girls' access, participation, and resistance. Journal of Research in Science Teaching, 37(8), 871-889.

Chambers, D. W. (1983). Stereotypic images of the scientist: The Draw-a-Scientist Test. Science Education, 67(2), 255-265. http://dx.doi.org/10.1002/sce.3730670213

Christenson, S. L., \& Hurley, C. M. (1997). Parents' and school psychologists' perspectives on parent involvement activities. School Psychology Review, 26, 111-120.

Dori, Y. J., \& Revitial, T. T. (2000). Formal and informal collaborative projects: Engaging in industry with environmental awareness. Science Education, 84, 95-113. http://dx.doi.org/10.1002/(SICI)1098-237X(200001)84:1<95::AID-SCE7>3.0.CO;2-W

Erb, T. O. (1981). Attitudes of early adolescents toward science, women in science, and science careers. In T. O. Erb (Eds.), Middle School Research: Selected Studies (pp. 108-118).

Farland-Smith, D. (2009). Exploring middle school girls' science identities: Examining attitudes and perceptions of science when working side-by-side with scientists. School Science and Mathematics, 109(7), 412-432.

Farland-Smith, D. (2012). Personal \& social interactions between young girls and scientists: Examining critical aspects for identity construction. Journal of Science Teacher Education, 23(1), 1-18.

Finson, K. D. (2002). A multicultural comparison of draw-a-scientist test drawings of eighth graders. Paper presented at the Annual International Conference of the Association of Educators of Teachers of Science, Charlotte, NC.

Fort, D. C., \& Varney, H. L. (1989). How students see scientists: Mostly male, mostly white, mostly benevolent. Science \& Children, 26(8), 8-13.

Gettys, L., \& Cann, A. (1981). Children's perceptions of occupational sex stereotypes. Sex Roles, 7(3), 301-308. http://dx.doi.org/10.1007/BF00287544

Giddens, A. (1991). Modernity and self-identity. Self and society in the late modern age. Cambridge: Polity Press.

Ho, E. S. C. (2010). Family influences on science learning among Hong Kong adolescents: What we learned from PISA. International Journal of Science and Mathematics Education, 8(3), 409-428. http://dx.doi.org/10.1007/s10763-010-9198-3

Hoover-Dempsey, K., \& Sandler, H. (1995). Why do parents become involved in their children's education? Review of Educational Research, 67(1), 3-43. http://dx.doi.org/10.3102/00346543067001003

Kaya, S., \& Lundeen, C. (2010). Capturing parents' individual and institutional interest 
toward involvement in science education. Journal of Science Teacher Education, 21(7), 825-841. http://dx.doi.org/10.1007/s10972-009-9173-4

Lave, J., \& Wenger, E. (1991). Situated Learning: Legitimate peripheral participation. Cambridge, England: Cambridge University Press. http://dx.doi.org/10.1017/CBO9780511815355

Lindahl, B. (2003). A desire to learn science and technology: A longitudinal study of pathways to upper secondary school (Doctoral Thesis, Goteborg Studies in Educational Sciences, Goteborg).

Lofland, J., \& Lofland, L. (1995). Analyzing social settings: A guide to qualitative observation and analysis. Belmont, Calif: Wadsworth.

Mead, M., \& Metraux, R. (1957). The image of the scientist amongst high school students. In B. Barbar \& W. Hirsch (Eds.), The Sociology of Science (pp. 38-61). Lewes, England: Falmer Press.

National Center for Education Statistics. (2009). NAEP High school transcript study 2009. Washington, DC: US Department of Education.

National Science Board. (2010). Science and engineering indicators 2010. Arlington, VA: National Science Foundation (NSB 10-01).

Rodriguez, A. J. (1998). Busting open the meritocracy myth: Rethinking equity and student achievement in science education. Journal of Women and Minorities in Science and Engineering, 4(2\&3). http://dx.doi.org/10.1615/JWomenMinorScienEng.v4.i2-3.80

Sadker, D., Sadker, M., \& Zittleman, K. (2009). Still failing at fairness: How gender bias cheats boys and girls in school and what we can do about it. New York, NY: Simon and Schuster.

Schibeci, R. A., \& Sorenson, I. (1983). Elementary school children's perceptions of scientists. School Science Mathematics, 83(1), 14-19. http://dx.doi.org/10.1111/j.1949-8594.198 3.tb10087.x

Schreiner, C., \& SJoberg, S. (2007). Science education and young people's identity construction-two mutally incompatible projects? In D. Corrigan, J. Dillon \& R. Gunstone (Eds.), The Re-emergence of values in the science curriculum. Rotterdam: Sense Publishers.

Siraj-Blatchford, I., \& Mayo, A. (2012). Social class and educational inequality: The impact of parents and schools. Cambridge: Cambridge University Press.

Storen, L. A., \& Arneson, C. A. (2003). A gender divided educational system. In M. Raabe, P. Aasen, P. O. Aamodt, N. M. Stolen, \& A. H. Hoisak (Eds.), Education 2003-resources, recruitment and results. Oslo: Statistik Sentralbyra, Statistics Norway.

Sun, L., Bradley, K. D., \& Akers, K. (2012). A multilevel modelling approach to investigating factors impacting science achievement for secondary school students: PISA Hong Kong sample. International Journal of Science Education, 34(14), 2107-2125. 
http://dx.doi.org/10.1080/09500693.2012.708063

Szechter, L. E., \& Carey, E. J. (2009). Gravitating toward science: Parent-child interactions as a gravitational-wave observatory. Science Education, 93(5), 846-858. http://dx.doi.org/10.1002/sce.20333

Tan, E., \& Calabrese-Barton, A. (2007). From peripheral to central, the story of Melanie's metamorphosis in an urban middle school science class. Science Education, 92(4), 567-590. http://dx.doi.org/10.1002/sce.20253

Tan, E., Calabrese-Barton, A., Kang, H., \& O’Neil, T. (2013). Desiring a career in STEM-related fields: How middle school girls articulate and negotiate identities-in-practice. Journal of Research in Science Teaching, 50(10), 1143-1179. http://dx.doi.org/10.1002/tea.21123

Tare, M., French, J., Frazier, B. N., Diamond, J., \& Evans, E. M. (2011). Explanatory parent-child conversation predominates at an evolution exhibit. Science Education, 95(4), 720-744. http://dx.doi.org/10.1002/sce.20433

\section{Copyright Disclaimer}

Copyright for this article is retained by the author(s), with first publication rights granted to the journal.

This is an open-access article distributed under the terms and conditions of the Creative Commons Attribution license (http://creativecommons.org/licenses/by/3.0/). 